\title{
Effect of irrigation on some growth parameters of cup plant and dehydrogenase activity in soil
}

\author{
ANNA FIGAS ${ }^{1}$, ANETTA SIWIK-ZIOMEK ${ }^{2}$, ROMAN ROLBIECKI ${ }^{3}$, \\ MAGDALENA TOMASZEWSKA-SOWA ${ }^{1}$ \\ ${ }^{1}$ Department of Plant Physiology and Fundamentals of Biotechnology \\ ${ }^{2}$ Department of Biochemistry \\ ${ }^{3}$ Department of Land Reclamation and Agrometeorology \\ UTP University of Science and Technology
}

\begin{abstract}
Effect of irrigation on some growth parameters of cup plant and dehydrogenase activity in soil. A field experiment carried out in two vegetation seasons in the years 2012 and 2013 on very light soil at Kruszyn Krajeński, in the vicinity of Bydgoszcz (Poland). Investigation of the influence of drip irrigation on some growth parameters of three- and four-year-old cup plant (Silphium perfoliatum L.) and on the activity of dehydrogenase participating at cycling in soil was examined. The cup plants were cultivated from the micropropagation seedlings. Experiments were performed as one factorial in four replications. The factor of the experiment was the following variants: $\mathrm{O}$ - without irrigation (control plots), $\mathrm{D}-$ with drip irrigation. Drip irrigation was scheduled according to tensiometers indications. Irrigation significantly increase the height of the plants, the length of internode, the thickness of the stalk, the fresh weight of the shoots, and the number of the leaves and flowers. Irrigation also increased the transpiration leaf area and the dry matter content. In the soil sampled under cup plant in 2012 there was found a greater activity of dehydrogenases in soil derived from non-irrigated objects.
\end{abstract}

Key words: drip irrigation, light soil, micropropagation, Silphium perfoliatum, soil enzymes

\section{INTRODUCTION}

Representing family Asteraceae, cup plant (Silphium perfoliatum L.) is a perennial reaching up to $2.5 \mathrm{~m}$ height. In the first year of growth the plant creates a rosette, generative shoots develop in successive years. Due to the production of big overground mass, the plant demonstrates high water and irrigation requirements. Cup plant is a plant of temperate climate with little soil requirements. In the natural environment it occurs in the central and eastern part of the United States as well as in the south of Canada. The optimal growth and development of cup plant require sunny sites and the temperature of air about $25^{\circ} \mathrm{C}$. It reacts to long-term periods of drought with dying of lower leaves and browning of buds. In an extreme case it stops growing, creates small flowers and a little amount of seeds (Stanford 1990, Kowalski and Wierciński 2004). Under the climatic conditions of Poland irrigation is the method of supplementing water deficits. Due to decreasing resources of disposable water for irrigation, more and more attention is paid to water-saving irrigation systems, the so-called microirrigation, including drip irrigation which is characterized with the high influence of the agricultural productivity effects (Pierzgalski and Jeznach 1993, Jeznach 2007 and 2009, Rolbiecki 
and Rolbiecki 2008). The preliminary results of the present research by Figas et al. (2011) point to the fact that cup plant is a plant predestined for growing under supplemental irrigation.

The plant can be grown for feed, ornamental, honey-producing and energy-generating purposes (Majtkowski 2007, Piłat et al. 2007, Decourtye et al. 2010, Țîtei et al. 2013, Wróbel et al. 2013, Jasinskas et. al. 2014) and as it has low soil requirements, it can be recommended as a pioneer plant for the recultivation of degraded areas (Klimont 2007). The herbage of cup plant is also a potentially precious material for food and pharmaceutical industries. The extracts from that plant show pain-killing, anti-inflammatory properties, promote sweating, as well as restorative, antibacterial, antifungal, expectorant properties as well as they can lower the level of cholesterol (El-Sayed et al. 2002, Kowalski and Wolski 2003a,b, Kowalski and Wierciński 2004, Kowalski 2005, Jemiołkowska and Kowalski 2012).

Irrigation, by changing water conditions, affects the population of microorganisms in soil. Dehydrogenases (EC 1.1.1) catalyze the transferring of hydrogen from oxidized substrates to acceptors and the dehydrogenases are active in all soil microorganisms; aerobic as well as anaerobic. Assays for dehydrogenase activity in soil have often been used to achieve the value of the index of total soil microbial activity (Brzezińska 2004).

Numerous functional properties of the cup plant and climatic conditions similar to those it occurs naturally can enhance the cultivation of that species in the country. However, the source of the sowing material, however, which occurs in
Poland do not satisfy a growing interest of the breeders. The technology which facilitates obtaining vegetative propagation material is the micropropagation of plants in cultures in vitro.

The aim of the present research was to investigate the effect of drip irrigation on selected parameters of growth of threeand four-year-old cup plants (Silphium perfoliatum L.), derived from micropropagation grown on light soil as well as defining the activity of dehydrogenases in soil.

\section{MATERIAL AND METHODS}

\section{Micropropagation in vitro}

The initial research material involved the seeds of cup plant (Silphium perfoliatum L.), which came from the Botanical Garden of the National Center of Plant Gene Resources of the Institute of Plant Breeding and Acclimatization (IHAR) in Bydgoszcz (Poland). To induce germination, sterilized embryos were placed onto the Murashige and Skoog medium - MS (Murashige and Skoog 1962), diluted at the ratio of $1: 1$ and solidified with $0.7 \%$ agar. From six-week sterile seedlings there were isolated apical parts of shoots. The explants were put into the test-tubes on the MS regeneration medium contained growth regulators: $1 \mathrm{mg} \cdot \mathrm{dm}^{-3}$ NAA (1-naphthaleneacetic acid) and $5 \mathrm{mg} \cdot \mathrm{dm}^{-3}$ BAP (6-enzylaminopurine). After about 6-8 weeks the shoots were isolated and transferred onto MS rooting medium without growth regulators. In vitro culture of plants was conducted in a phytotron under controlled environmental conditions: a 16-hour photoperiod at a light intensity of $40 \mu \mathrm{mol} \cdot \mathrm{m}^{-2} \cdot \mathrm{s}^{-1}$ and a constant temperature of $25 \pm 2^{\circ} \mathrm{C}$. 
The rooted plants were transferred into the mixture of sterile soil and perlite $(1: 1)$ and acclimatized under greenhouse conditions.

\section{Field trial}

The field experiment with drip irrigation of the cup plants was carried out in the years $2012-2013$ at the very light soil (type - Mollisoil; texture - Fine sand) in Kruszyn Krajeński in the vicinity of Bydgoszcz $\left(53^{\circ} 04^{\prime} 53^{\prime \prime} \mathrm{N}, 1^{\circ} 51^{\prime} 52^{\prime \prime}\right.$ E). The soil characteristic is shown in Table 1. The water reserve to soil depth of $1 \mathrm{~m}$ at field capacity was $87 \mathrm{~mm}$ and the available water quantity was $67 \mathrm{~mm}$. The soil was characterized by the low organic matter content $(1.5 \%)$. The cup plants were cultivated from the micropropagation seedlings planted in 2010 . The experiment was performed as a one-factorial in four replications. The factor of the experiment was the following variants: $\mathrm{O}$ - without irrigation (control plots), D - with drip irrigation. Drip irrigation was scheduled according to tensiometers indications, installed at $25 \mathrm{~cm}$ depth. The irrigation was started when the soil water pressure was up to $-0.04 \mathrm{MPa}$. The irrigation water rates were strictly connected with the rain distribution and amounted to 116 and $108 \mathrm{~mm}$ for 2012 and 2013 respectively. The single rates of water ranged from 6 to $12 \mathrm{~mm}$. Irrigation was done with the drip line "T-Tape" with the distance among the dripers $30 \mathrm{~cm}$. The agrotechnical practises and fertilization adopted were the standard used across the country. The mineral fertilization was applied at the rates of $500 \mathrm{~kg}$ $\mathrm{N}: \mathrm{P}: \mathrm{K} \cdot \mathrm{ha}^{-1}$ at the ratio of $2: 2: 3$. Doses of potassium (potash salt) and phosphorus (superphoshate) fertilization were dependent on the abundance of these nutrients in the soil. The nitrogen fertilization (ammonium nitrate) was supplied at three single rates. The area of single experimental plot was equal to $11 \mathrm{~m}^{2}$. The seedlings were planted with a row spacing of $1 \mathrm{~m}$. The plant spacing was $0.7 \mathrm{~m}$.

\section{The height and plant parameters of cup plant and dehydrogenases activity analysis}

Measurements of the growth parameters were performed in the first decade of October, in each of the years of research. In the experiment rated the height of the plants $(\mathrm{cm})$, the length of internode $(\mathrm{cm})$, the fresh matter of the shoots $\left(\mathrm{kg} \cdot\right.$ plant $\left.^{-1}\right)$, dry matter of the leaves (\%), the number of the leaves, the thickness of the stalk (mm), number of flowers on shoot and leaf area $\left(\mathrm{cm}^{2}\right)$. Measurements of the stem thickness measured by caliper. The height of the plants was measured in $\mathrm{cm}$ from the soil surface to the top of the

TABLE 1. Physical properties of the soil

\begin{tabular}{|c|c|c|c|c|c|c|c|}
\hline \multirow{3}{*}{$\begin{array}{l}\text { Genetic } \\
\text { horizon }\end{array}$} & \multirow{3}{*}{$\begin{array}{l}\text { Depth } \\
(\mathrm{cm})\end{array}$} & \multirow{3}{*}{ Texture } & & \multicolumn{2}{|c|}{ Bulk density } & \multirow{2}{*}{ Porosity } & \multirow{2}{*}{ Moisture } \\
\hline & & & Specific density & temp. & actual & & \\
\hline & & & \multicolumn{3}{|c|}{$\mathrm{Mg} \cdot \mathrm{m}^{-3}$} & \multicolumn{2}{|c|}{$\%$ vol. } \\
\hline Ap & $0-33$ & slightly loamy sand & 2.290 & 1.426 & 1.324 & 42.2 & 10.2 \\
\hline $\mathrm{AC}$ & $33-60$ & loose sand & 2.680 & 1.620 & 1.591 & 40.6 & 2.9 \\
\hline $\mathrm{C}$ & $60-150$ & loose sand & 2.740 & 1.691 & 1.653 & 39.7 & 3.8 \\
\hline
\end{tabular}


shoot apex. For leaf area measurement the digital planimeter was used. Samples of the leaves were oven-dried at $105^{\circ} \mathrm{C}$ and their dry weights were determined.

In the adequately prepared plant material the following were assayed: total organic carbon (TOC) and total nitrogen (TN) were determined with the analyser TOC Primacs provided by Scalar.

Soil samples were taken from the top of 0-30 cm using an auger during cup plant vegetation in August 2012 and 2013. Soils were, respectively. Then the air-dried soils were sieved using sieve with holes of below $2 \mathrm{~mm}$ in diameter. Meanwhile, the sampled soil water content was determined using an oven-drying method, so as to calculate soil enzymatic activities per $g$ of dry soil. Dehydrogenase activity was measured using triphenyltetrazolium chloride as a substrate; samples were incubated for $24 \mathrm{~h}$ at $37^{\circ} \mathrm{C}$ with the Thalmann (1968) method.

\section{Statistical analysis}

The analysis of variance was performed using all the results applying FR-ANALWAR software based on Microsoft Excel (Rudnicki 2011). The significance of differences was evaluated by the Tukey's test and LSDs were calculated at a significance level of $\alpha=0.05$.

\section{RESULTS AND DISCUSSION}

The mean height of cup plants on control plots (without irrigation) in the research period of 2012-2013 was equal to $98.63 \mathrm{~cm}$ (Table 2). Drip irrigation had a significant effect on an increase in the mean plant height by $35.08 \mathrm{~cm}(35.6 \%)$. The increase in the cup plant height was due to an increase in the length of inter- nodes. Their mean length was $14.23 \mathrm{~cm}$, both on the objects irrigated and non-irrigated. Drip irrigation increased the length of internodes by $45.3 \%$.

Drip irrigation significantly affected the fresh weight of shoots in 3- and 4-year-old cup plants (Table 2). The experimental factor applied resulted in, on average over the research period of 2012-2013, its significant increase by $2.56 \mathrm{~kg}$. The mean fresh weight of shoots from the plants collected from the irrigated objects was equal to $4.41 \mathrm{~kg} \cdot$ plant $^{-1}$. Similar tendencies of the growth of fresh weight of leaves due to the application of drip irrigation was found in the case of one-year-old cup plants (Figas et al. 2011).

In the experiment the content of dry weight in the leaves of cup plant accounted for, on average in the research years and on average for the variants of the experiment of $19.17 \%$ (Table 2). The application of irrigation significantly increased the content of dry weight in leaves by $35.4 \%$. Figas et al. (2011) performing research with the irrigation of one-year-old cup plants recorded a significant increase in the value of that parameter by $17.6 \%$. In this experiment it ranged from 14.33 to $22.95 \%$, respectively on the control objects and the drip-irrigated ones. Similar values of the content of dry weight in the leaves of cup plant are reported by Stanford (1990), accounting for $21.5 \%$. The tendencies to increase the content of dry weight in the irrigate plants coincide with the reports on other plant species (Pronk et al. 2005, Wichrowska et al. 2007).

The mean number of leaves per stem was equal to 16.45 (Table 2). The number of leaves on control objects was 14.34 and on the objects treated with drip 


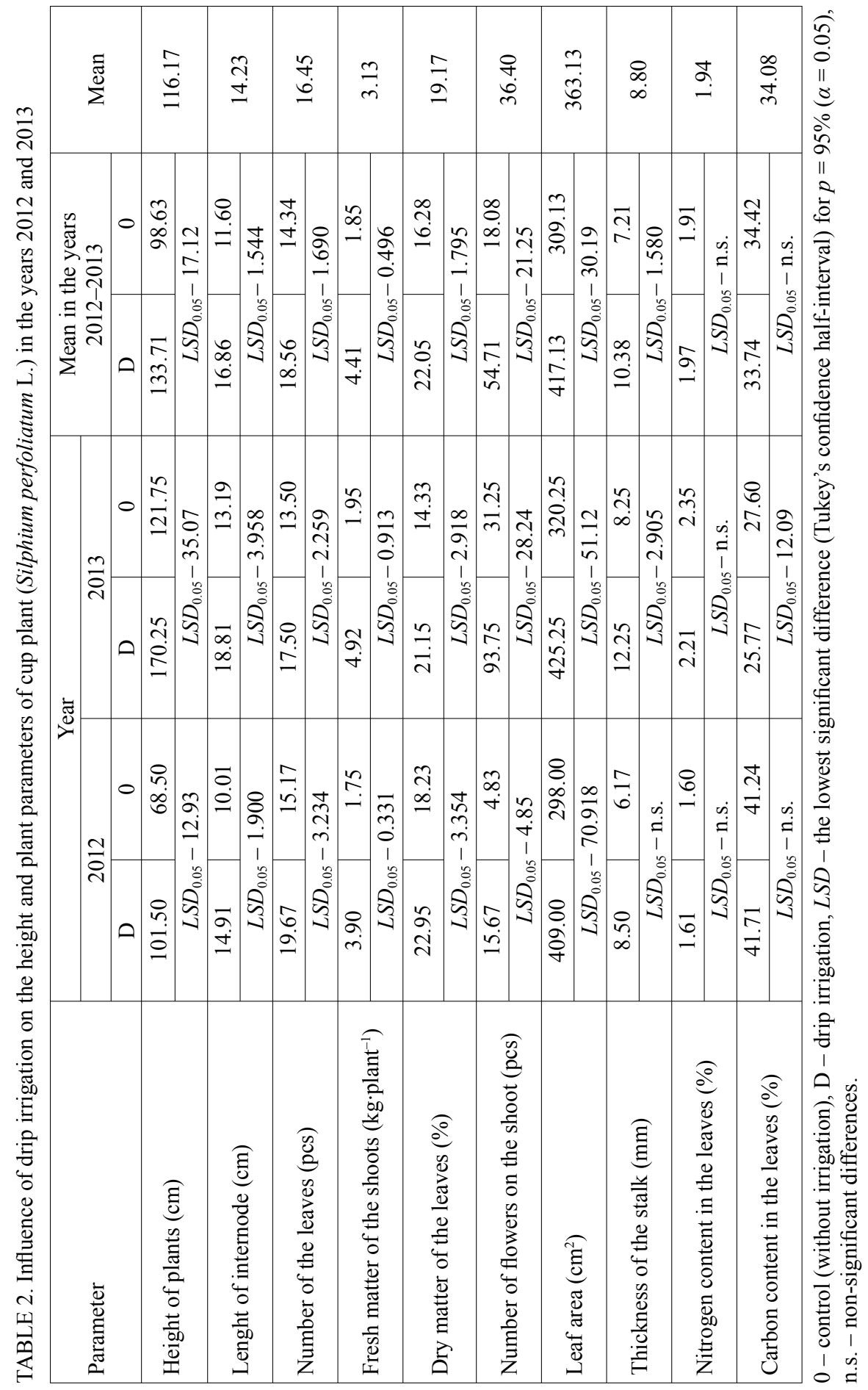


irrigation - 18.56. Stanford (1990) claims that the plant can have 8 to 14 pairs of stem leaves. The increase in the number of leaves as a result of the irrigation used was significant and it was equal to 4.22. The regularity recorded coincides with earlier research results on the drip irrigation of the one-year-old cup plants (Figas et al. 2011) as well as other nursery plants (Rolbiecki et al. 2005, Klimek et al. 2009).

The drip irrigation applied increase the average leaf area three- and 4-year-old cup plants as compared with the control objects on average by $108 \mathrm{~cm}^{2}$ (Table 2). The leaf area measured from control objects was equal to $309.13 \mathrm{~cm}^{2}$, on the irrigated objects was higher and equal to $417.13 \mathrm{~cm}^{2}$. Similar tendencies in affecting the leaf area were reported by Rolbiecki et al. (2005), Klimek et al. (2009) and Figas et al. (2011).

Over 2012-2013 years the mean number of flowers per plant both on the irrigated and non-irrigated objects was equal to 36.40 (Table 2). In this experiment drip irrigation significantly increased the number of flowers per plant by as much as $202.6 \%$ (36.63). The result is confirmed by Koszański et al. (2008) on the irrigation of northern highbush blueberry (Vaccinium corymbosum L.) as a result of which the authors recorded a two-fold increase in the mean number of flowers on irrigated objects (Table 3).

In the analyzed two years of this research there was found no effect of drip irrigation on the content of organogenic elements such as carbon and nitrogen in cup plants (Table 2). As reported by Trawczyński (2012), the irrigation treatments can affect the yield size more considerably than the content of nutrients in plants.

The water-air conditions in soil regulate the activity of microorganisms, affecting their type of metabolism as well as a number of adaptations they must develop as a response to the existing environmental conditions (Gleeson et al. 2008). Soil dehydrogenase activity increases under anaerobic conditions (Brzezińska 2004).

In the soil sampled under cup plant in 2012 there was found a greater activity of dehydrogenases in the soil from the non-irrigate objects (Fig. 1). The activity was $71 \%$ higher as compared with the objects exposed to drip irrigation. Such a high difference of the index of micro-

TABLE 3. Air temperature and rainfall data during the two vegetation period of cup plant by monthly measurements in the period of 1981-2010 and the years 2012 and 2013

\begin{tabular}{|c|c|c|c|c|c|r|}
\hline \multirow{2}{*}{ Specification } & \multicolumn{7}{|c|}{ Air temperature $\left({ }^{\circ} \mathrm{C}\right)$} \\
\cline { 2 - 7 } & V & VI & VII & VIII & IX & V-IX \\
\hline 2012 & 14.5 & 15.2 & 18.8 & 17.6 & 13.3 & 15.9 \\
\hline 2013 & 14.2 & 14.4 & 18.9 & 18.1 & 10.7 & 15.3 \\
\hline Long period 1981-2010 & 13.1 & 16.0 & 18.5 & 17.9 & 13.2 & 15.7 \\
\hline$\times$ & \multicolumn{7}{|c|}{ Rainfall (mm) } \\
\hline 2012 & 25.4 & 133.8 & 115.6 & 51.8 & 25.1 & 351.7 \\
\hline 2013 & 91.7 & 49.3 & 79.0 & 56.6 & 64.1 & 340.7 \\
\hline Long period 1981-2010 & 49.3 & 52.8 & 69.8 & 62.6 & 46.0 & 280.5 \\
\hline
\end{tabular}




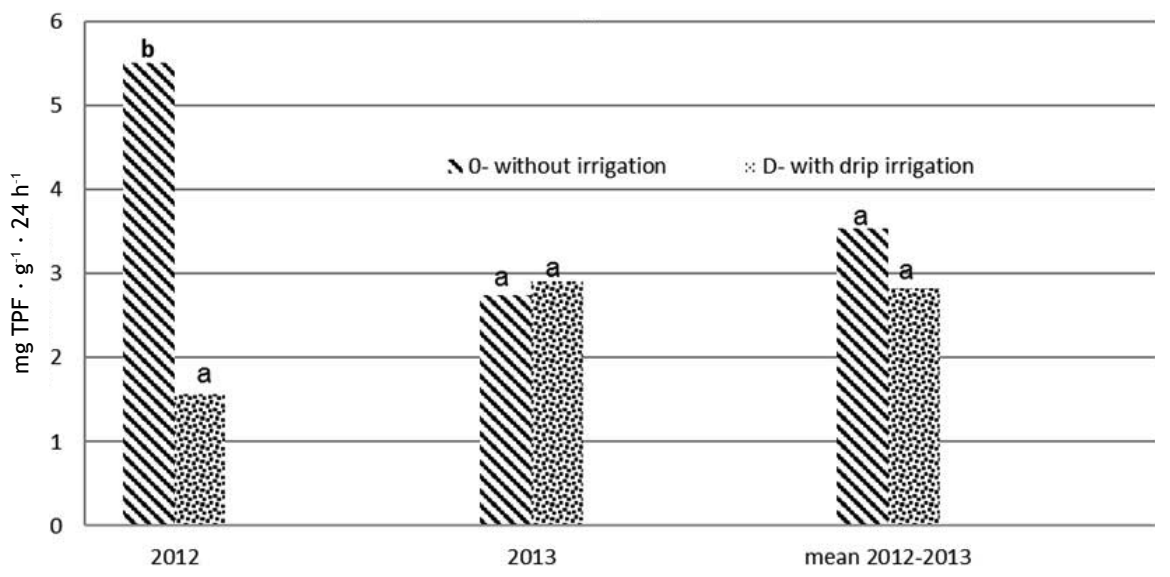

$\mathrm{a}, \mathrm{b}-$ values followed by the same letter are not significantly different at $p<0.05$

FIGURE. Dehydrogenase activity in the instigated soil under cup plant in the years 2012 and 2013

biological soil activity can be due to the occurrence of anaerobic conditions in the soil sampled from control objects with cup plant. In 2012 most rainfall coincided in the summer season (June - August), while in spring the rainfall did not practically occur at all (Table 3 ). Water stress caused by periodical drought and then rapid soil environment irrigation get quickly reflected in the nature of the community of microorganisms (Young and Ritz 2000). According to Gleeson et al. (2008), under soil irrigation conditions, after a long period of drought, there occurs decay of the cells of microorganisms connected with a release of intracellular enzymes from them. After the spring period of low rainfall, in June there was reported an intensive soil irrigation (rainfall of $133.8 \mathrm{~mm}$ ) and intensified microbiological activity of soil. In the irrigate soil the stabilizing availability of water did not affect so intensively on the activity of dehydrogenases in the soil. Xiang et al. (2008) found a five-fold higher activity of dehydrogenases in the flooded soil, as compared with the con- ditions of dry soils. Such a direction of transformations points to an increased share of anaerobic bacteria, the habitat of which are moist soil environments in the formation of the activity of dehydrogenases of soils (Pascual et al. 2007). In the successive year of the vegetation period of cup plant, there was found no significant effect of drip irrigation on the activity of dehydrogenases in soil (Fig.).

The activity of dehydrogenases in the soil collected from the objects exposed to drip irrigation, was $6 \%$ lower, as compared with the control. Most probably high rainfall $(91.7 \mathrm{~mm})$ and temperature $\left(14.2^{\circ} \mathrm{C}\right)$ in May at Kruszyn Krajeński eliminated the stabilizing effect of irrigation on the development of soil microflora, which did not cause such a high variation in the activity of dehydrogenases.

\section{CONCLUSIONS}

1. Under Bydgoszcz climatic conditions the plant is capable for the cultivation under field conditions on light soil and it shows a significant increase in the 
parameters of growth of aboveground parts as a result of drip irrigation.

2. It was shown that the effect of drip irrigation and rainfall during wet plant vegetation cup plant in 2012 increased on the activity of dehydrogenases which are a sensitive indicator of the changes which occur in the environment of soil microorganisms. The air-water status in soil plays an important role in the regulation of the composition and metabolic activity of soil microorganisms.

\section{REFERENCES}

BRZEZIŃSKA M. 2004: Aeration status of soil end enzyme activity. In: J. Gliński, G. Józefaciuk, K. Stahr (Eds). Soil - Plant Atmosphere and environmental problems. PAN, Lublin - Stuttgart, 55-59.

DECOURTYE A., MADER E., DESNEUX N. 2010: Landscape enhancement of floral resources for honey bees in agro-ecosystems. Apidologie 41, 264-277.

El-SAYED N.H., WOJCIŃSKA M., DROST-KARBOWSKA K., MATŁAWSKA I., WILLIAMS J., MABRY T.J. 2002: Kaempferol triosides from Silphium perfoliatum. Phytochemistry 60, 835-838.

FIGAS A., ROLBIECKI R., TOMASZEWSKA-SOWA M. 2011: Wpływ nawadniania kroplowego na wzrost rożnika przerośniętego (Silphium perfoliatum L.) uprawianego na glebie bardzo lekkiej z sadzonek uzyskanych w wyniku mikrorozmnażania [Influence of drip irrigation on the height of cup plant (Silphium perfoliatum L.) cultivated on the very light soil from the micropropagation seedlings]. Infrastructure and Ecology of Rural Areas 10, 245-253 (Engl. summ.).

GLEESON D.B., HERRMANN A.M., LIVESLEY S.J., MURPHY D.V. 2008: Influence of water potential on nitrification and structure of nitrifying bacterial communities in semiarid soils. Appl. Soil Ecol. 40, 189-194.

JASINSKAS A., SIMONAVIČIŪTE R., ŠIAUDINIS G., LIAUDANSKIENË I.,
ANTANAITIS Š., ARAK M., OLT J. 2014: The assessment of common mugwort ( $\mathrm{Ar}$ temisia vulgaris L.) and cup plant (Silphium perfoliatum L.) productivity and technological preparation for solid biofuel. Zemdirbyste-Agriculture 101 (1), 19-26.

JEMIOŁKOWSKA A., KOWALSKI R. 2012: In vitro estimate of influence of Silphium perfoliatum L. leaves extract on some fungi colonizing the pepper plants. Acta Sci. Pol., Hort. Cult. 11 (3), 43-55.

JEZNACH J. 2007: Some maintenance problems of the drip irrigation in Poland. Ann. Warsaw Univ. Life Sci. - SGGW, Land Reclam. 38, 41-47.

JEZNACH J. 2009: Aktualne trendy rozwoju mikronawodnień. Infrastruktura $i$ Ekologia Terenów Wiejskich 6, 83-94.

KLIMEK A., ROLBIECKI S., ROLBIECKI R., NALCZYK P. 2009: Impact of chosen bare root nursery practices on white birch seedling quality and soil mites (Acari). Polish J. of Environ. Stud. 18 (9), 1011-1018.

KLIMONT K. 2007: Ocena przydatności wybranych gatunków roślin użytkowych do rekultywacji terenów zdewastowanych przez przemysł i gospodarkę komunalną [Evaluation of the usefulness of selected species of crop plants for remediation of land devastated by industry and municipal economy]. Problems of Agricultural Engineering 2, 27-36 (Engl. summ.).

KOSZAŃSKI Z., RUMASZ-RUDNICKA E., FRIEDRICH S. 2008: Wpływ nawadniania i nawożenia NPK na budowę anatomiczną i morfologiczną oraz plonowanie borówki wysokiej (Vaccinium corymbosum L.) [Anatomy, morphology and yield of highbush blueberry (Vaccinium corymbosum L.) under the influence of irrigation and mineral fertilization]. Acta Agrophysica 11 (3), 677-684 (Engl. summ.).

KOWALSKI R., WOLSKI T. 2003a: TLC and HPLC analysis of the phenolic acids in Silphium perfoliatum L. leaves, inflorescences and rhizomes. Journal of Planar Chromatography 16, 230-236.

KOWALSKI R., WOLSKI T. 2003b: Evaluation of phenolic acid content in Silphium perfoliatum L. leaves, inflorescences and rhizomes. EJPAU Horticulture 6 (1): \#03. http://www. ejpau.media.pl/volume6/issue1/horticulture/ abs-03.html. 
KOWALSKI R., WIERCIŃSKI J. 2004: Ocena niektórych gatunków Silphium jako surowców inulinowych [Evaluation of some Silphium species as alternative inulin raw materials]. Annales UMCS, Sec. E 59 (1), 189-195 (Engl. summ.).

KOWALSKI R. 2005: Analysis of lipophilic fraction from leaves, inflorescences and rhizomes of Silphium perfoliatum L. Acta Soc. Bot. Pol. 74 (1), 5-10.

MAJTKOWSKI W. 2007: Problems of biomass market creation in Poland. Problems of Agricultural Engineering 1, 155-162.

MURASHIGE T., SKOOG F. 1962: A revised medium for rapid growth and bioassay with tobacco tissue cultures. Physiol. Plant. 15, 473-497.

PASCUAL I., ANTOLIN M. C., GARCIA C., POLO A., SANCHEZ-DIAZ M. 2007: Effect of water deficit on microbial characteristics in soil amended with sewage sludge or inorganic fertilizer under laboratory conditions. Bioresource Technol. 98, 29-37.

PIERZGALSKI E., JEZNACH J. 1993: Stan i kierunki rozwoju mikronawodnień. In: C. Somorowski (Ed.). Współczesne problemy melioracji. Wyd. SGGW, Warszawa, 35-42.

PIŁAT J., MAJTKOWSKI W., MAJTKOWSKA G., MIKOŁAJCZAK J., GÓRALSKAA. 2007: The usefulness for ensiling of chosen plant forms of species of Silphium genus. Journal of Central European Agriculture 8 (3), 363-368.

PRONK A.A., HEINEN M., CHALLA H. 2005: Dry mass production and water use of non- and drip-irrigated Thuja occidentalis 'Brabant': Field experiments and modeling. Plant and Soil 268, 329-347.

ROLBIECKI R., ROLBIECKI S. 2008: Effect of surface drip irrigation on asparagus cultivars in central Poland. Acta Horticulture 776, 45-50.

ROLBIECKI S., ROLBIECKI R., KLIMEK A. 2005: Effect of microirrigation and organic fertilization on the two-year old seedling production of verrucose birch (Betula verrucosa $\mathrm{E}$.) with the applcation of zoo-melioration treatment. Zesz. Probl. Post. Nauk Rol. 506, 345-353.

RUDNICKI F. 2011: FR-ANALWAR software based on Microsoft Excel, Bydgoszcz.

STANFORD G. 1990: Silphium perfoliatum (cup-plant) as a new forage. Proceedings of $12^{\text {th }}$ North American Prairie Conference, Cedar Falls, 33-37.
THALMANN A. 1968: Zur methodik der bestimmung der dehydrogenases aktivität in boden mittels triphenyltetrazoliumchlorid (TTC) [Methods of dehydrogenase activity determination with triphenyltetrazoliumchlorid (TTC)]. Landwirtsch. Forsch. 21, 249-258 (Engl. summ.).

ȚîȚEI V., TELEUȚĂ A., MUNTEA A. 2013: The perspective of cultivation and utilization of the species Silphium perfoliatum L. and Helianthus tuberosus L. in Moldova. Bulletin UASMV, Agriculture 7 (1), 160-166.

TRAWCZYŃSKI C. 2012: The influence of irrigation and effective microorganisms on quantity and chemical composition of the yields of plants cultivation in organic crop rotation on light soil. J. Res. Appl. Agric. Engng 57 (4), 148-154 (Engl. summ.).

WICHROWSKA D., WOJDYŁA T., ROLBIECKI St., ROLBIECKI R., PISZCZEK P. 2007: Content of selected components in fruits of Polish watermelon cultivar 'Bingo' as dependent on the method of the seedling production and irrigation. Pol. J. Food Nutr. Sci. 57 (3A), 147-149.

WRÓBEL M., FRĄCZEK J., FRANCIK S., SLIPEK Z., MUDRYK K. 2013: Influence of degree of fragmentation on chosen quality parameters of briquette made from biomass of cup plant Silphium perfoliatum L. Conference Engineering for Rural Development, Jelgava, Latvia, 653-657.

XIANG S.R., DOYLE A., HOLDEN P.A., SCHIMEL J.P. 2008: Drying and rewetting effects on $\mathrm{C}$ and $\mathrm{N}$ mineralization and microbial activity in surface and subsurface California grassland soils. Soil Biol. Biochem. 40, 2281-2289 .

YOUNG I.M., RITZ K. 2000: Tillage, habitat space and function of soil microbes. Soil Till. Res. 53: 201-213.

Streszczenie: Wplyw nawadniania na wybrane parametry wzrostu rożnika przerośniętego $i$ zawartość dehydrogenazy w glebie. Doświadczenie polowe przeprowadzono $\mathrm{w}$ dwóch sezonach wegetacyjnych w latach 2012 i 2013 na glebie bardzo lekkiej w Kruszynie Krajeńskim w pobliżu Bydgoszczy. Badano wpływ nawadniania na niektóre parametry wzrostu 3- i 4-letnich roślin rożnika przerośniętego (Silphium perfoliatum L.) 
oraz na aktywność dehydrogenaz uczestniczących w przemianach zachodzących w środowisku glebowym. Doświadczenie założono jako jednoczynnikowe w czterech powtórzeniach. Czynnikiem stanowiącym źródło zmienności było nawadnianie kroplowe. Zastosowano dwa warianty doświadczenia: $\mathrm{O}$ - bez nawadniania (kontrola), $\mathrm{K}$ - nawadnianie kroplowe, przeprowadzane na podstawie wskazań tensjometrów $(-0,04 \mathrm{MPa})$. Materiałem do badań były rośliny rożnika przerośniętego (Silphium perfoliatum L.), które uzyskano w procesie mikrorozmnażania. Nawadnianie istotnie zwiększyło wysokość roślin, długość międzywęźli, grubość łodygi, świeżą masę pędów oraz liczbę liści i kwiatów. Nawadnianie zwiększyło również powierzchnię transpiracyjną liścia oraz zawartość suchej masy. Większą aktywność dehydrogenaz spod uprawy rożnika stwierdzano w glebie pobranej w 2012 roku z obiektów nienawadnianych.

Stowa kluczowe: nawadniania kroplowe, gleba lekka, mikrorozmnażanie, Silphium perfoliatum, enzymy glebowe

MS. received November 2015
Authors' addresses:

Anna Figas, Magdalena Tomaszewska-Sowa

Katedra Genetyki, Fizjologii i Biotechnologii

Roślin

Wydział Rolnictwa i Biotechnologii

Uniwersytet Technologiczno-Przyrodniczy

w Bydgoszczy

ul. Bernardyńska 6, 85-029 Bydgoszcz, Poland

e-mail: figasanna@utp.edu.pl magda@utp.edu.pl

Anetta Siwik-Ziomek

Zakład Biochemii

Katedra Gleboznawstwa i Ochrony Gleb

Wydział Rolnictwa i Biotechnologii

Uniwersytet Technologiczno-Przyrodniczy

w Bydgoszczy

ul. Bernardyńska 6, 85-029 Bydgoszcz, Poland e-mail: ziomek@utp.edu.pl

Roman Rolbiecki

Katedra Melioracji Agrometeorologii

Wydział Rolnictwa i Biotechnologii

Uniwersytet Technologiczno-Przyrodniczy

w Bydgoszczy

ul. Bernardyńska 6, 85-029 Bydgoszcz, Poland

e-mail: rolbr@utp.edu.pl 